\title{
Emendation of the foraminiferal genus Cribrostomoides Cushman, 1910, and its taxonomic implications
}

\author{
ROBERT W. IONES \\ $B P$ Exploration (Frontier $\mathcal{E}$ International), \\ 5 Long Walk, Stockley Park, Uxbridge, \\ Middlesex, UB11 1BP, U.K.
}

\author{
HEIKE BENDER \\ Geologisches Institut der Universität Kiel, \\ Ludwig Meyn Str. 12, D-2300 Kiel 1. \\ Germany.
}

\author{
MICHAEL A. CHARNOCK \\ Simon Petroleum Technology, \\ Ty'n y Coed, Llanrhos, Llandudno, \\ Guynedd, LL30 1SA, U.K.
}

\author{
MICHAEL A. KAMINSKI \\ Postgraduate Unit of Micropalaeontology, \\ University College London, Gower Street, \\ London, WCIE 6BT, U.K.
}

\author{
JOHNE. WHITTAKER \\ Department of Palaeontology, \\ The Natural History Museum, Cromwell \\ Road, London, SW7 5BD, U.K.
}

\begin{abstract}
A review of the taxonomic history of the agglutinated (benthonic) foraminiferal genus Cribrostomoides Cushman, 1910 reveals much confusion concerning its type species, coiling mode and apertural characteristics. We believe the originally designated type species of Cribrostomoides Cushman, 1910, C. bradyi Cushman, 1910, to be no more than varictally (i.e. infra-subspecifically) distinct from, and therefore a junior synonym of, Haplophragmoides subglobosus Cushman, 1910. The coiling of Cribrostomoides, as typified by C. subglobosus (Cushman, 1910), is in the form of an involute streptospire characterised by a repeated alternation in axis. The aperture of the genus is equatorially or asymmetrically placed and interio-areal and single (in megalospheric and juvenile microspheric specimens) to areal and multiple (in microspheric adults). In order to stabilise the concept of Cribrostomoides, we have designated lectotypes for both C. bradyi and H. subglobosus, and have also emended the generic diagnosis of Loeblich and Tappan (1987). Criteria for the discrimination of Cribrostomoides emend. herein and allied genera are tabulated. J. Micropalacontol. 12 (2): 181-193, December 1993.
\end{abstract}

\section{INTRODUCTION}

The lituolid (agglutinated benthonic foraminiferal) genus Cribrostomoides Cushman, 1910 is an ubiquitous component of modern deep-sea faunas. It has also been reported by numerous authors from "flysch-type" foraminiferal assemblages of Late Cretaceous to Oligocene age.

Unfortunately, this widely cited genus does not benefit from having a well-defined description. There is much confusion in the literature concerning its type-species, coiling mode and apertural characteristics. This is partly attributable to the poor quality of the original illustrations, and to the fact that the original description was based solely upon the external morphology of the test. The purpose of the present study is to stabilise the concept of Cribrostomoid's based upon lectotypification of the type species (and cmendation of the generic diagnosis). For this purpose we have illustrated type specimens from the collections of J.A. Cushman, H.B. Brady, and G.O. Sars, and have dissected specimens to reveal the mode of coiling and wall structure.

\section{TAXONOMIC HISTORY OF THE GENUS CRIBROSTO- MOIDES CUSHMAN, 1910}

In his "North Pacific Monograph", Cushman (1910: 108-109) first described the new genus Cribrostomoides, with the new species $C$. bradyi as the type. The type description for $C$. bradtil reads thus:

"Test free, planospiral, of several coils, chambered, the last-formed coil with several chambers progressively increasing in size, arenaceous wall, with much cement..., aperture in young specimens a simple elongate slit at the base of the apertural face, later subdivided by tooth-like processes, and in the adult represented by a linear series of distinct rounded [interio-areal or areal] openings." The type figures are reproduced in Fig. 1.1a-c.

In his subsequent "North Atlantic Monograph", Cushman (1920: 52-54) acknowledged the possibility that Cribrostomoides bradyi might be synonymous with Haplophragmoides subglobosum (Sars) (sic). However, he retained the two as separate species, stating that "Cribrostomoides may be easily distinguished in the adult by the row of pores forming the aperture, while the aperture of H. subglobosum is always simple."

In their studies of "Upper Cretaceous" [Palaeocene] material from the Lizard Springs Formation of Trinidad, Cushman \& Jarvis $(1927,1932)$ applied the generic name Cribrostomoides to a species (C. trinitatensis Cushman \& Jarvis, 1927) characterised by multiple interio-marginal rather than interio-areal openings, in so doing implicitly emended the concept of the genus. In fact, "Cribrostomoides" trinitatensis appears distinct from Cribrostomoides s.s. in its 


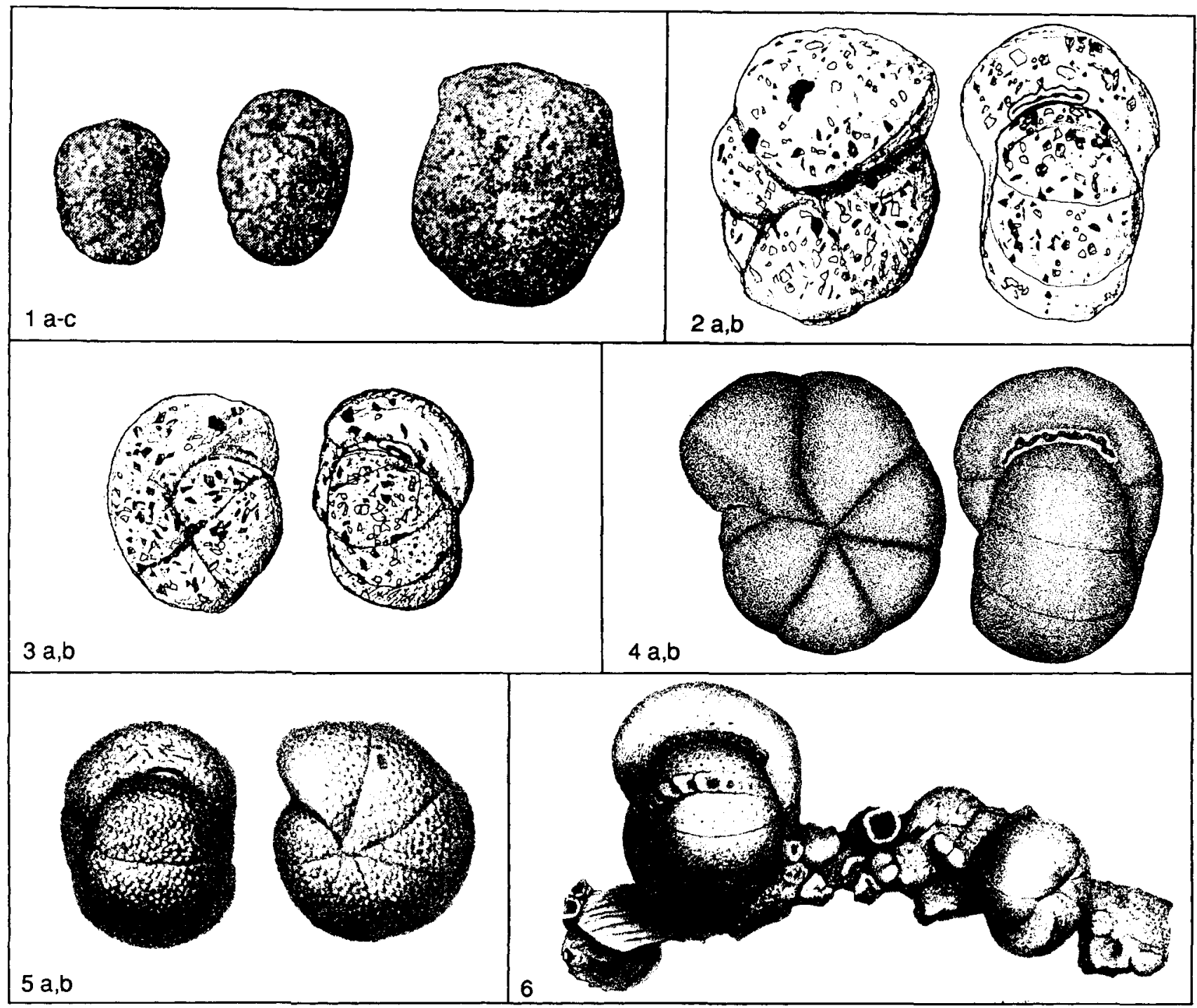

Fig. 1.1. Cribrostomoides subglobosus forma subglobosus (Cushman, 1910). x32. Reproduction of type figures of Haplophragmoides subglobostis Cushman, 1910, (Textfigs. 102-104). Textfig. 104 from Albatross Station D3603 (1771fm or 3241m). Fig. 1.2. Cribrostomoides subglobostis forma subglobosus (Cushman, 1910). x36. Lectotype of Haplophragmoides subglobosus Cushman, 1910 (herein designated). From Albatross Station D3603 (1771fm or 3241m). United States National Museum Registered Number USNM8219b. Specimen illustrated by Cushman (1910) as Textfig. 164. Compare with our Fig. 1.1. Also illustrated by SEM in Pl. 1, figs. 1a,b. Fig. 1.3. Cribrostomoides subglobosus forma subglobosus (Cushman, 1910). x36. Paralectotype of Haplophragmoides subglobosus Cushman, 1910 (herein designated). From Albatross Station D3603 (1771fm or 3241m), USNM8219b. Specimen illustrated by Cushman (1910) as Textfig. 162. Fig. 1.4. Cribrostomoides subglobosus forma bradyi (Cushman, 1910). x16. Reproduction of type figure of Cribrostomoides bradyi Cushman, 1910 (Textfig. 167). From Albatross Station D3346, North Pacific. Fig. 1.5. Cribrostomoides subglobosus forma subglobosus (Cushman, 1910). x20. Reproduction of P1. 34, fig. 8 of Brady (1884) (identified as Haplophragmium latidorsatum (Bornemann)). From Challenger Station 24, off Culebra Island, West Indies (390 fm or $714 \mathrm{~m}$ ). The Natural History Museum (BMNH) Registered Number ZF1542. Placed by Cushman (1910) in Haplophragmoides subglobosus G.O. Sars (sic). Fig. 1.6. Cribrostomoides subglobosus forma bradyi (Cushman, 1910). x15. Reproduction of Pl. 34, fig. 9 of Brady (1884) (identified as Haplophragmitum latidorsatum (Bornemann)). From Challenger Station 246, North Pacific (2050fm or 3752m), BMNH ZF1543. Placed by Cushman (1910) in Cribrostomoides bradyi n. sp. For a modern SEM illustration see Fig. 2.3.. 
interio-marginal rather than interio-areal aperture (and from Barkerina Frizzell \& Schwartz, 1950 (where it was placed by Frizzell \& Schwartz (1950)) in its arenaceous rather than microgranular wall and in lacking internal partitions). We believe "C. trinitatensis" probably represents a separate genus.

Höglund (1947: 144-145) synonymised Cribrostomoides Cushman, 1910 with Labrospira n. gen., apparently rejecting it on the grounds of the inappropriateness of the name (observing a complete gradation from specimens with simple slit-like apertures ("Labrospira") to rare specimens with multiple apertures ("Cribrostomoides") and arguing that Cushman was "...in no way justified..." in "...singling out such specimens [as the latter] and setting them up ... as a... new genus"). In fact, Articles 18 and $23 \mathrm{~m}$ of the International Code of Zoological Nomenclature (Ride et al., 1985) state that the "inappropriateness" of a name does not affect its availability, and that no valid available name can be rejected on this or any other ground. Moreover, Höglund also synonymised the type-species of Cribrostomoides Cushman, 1910 (C. bradyi Cushman) with Labrospira subglobosa (G.O. Sars, 1871 (1872)) (sic), in so doing, automatically making Labrospira a junior synonym of Cribrostomoides

Frizzell \& Schwartz (1950: 3) emended Cribrostomoides on the basis of its apertural characteristics, citing as typical a simple "elliptical or crescent-shaped" slit, located "...slightly above..." the base of the septal face and "...completely surrounded by it...". They added that "provisionally, it scems advisable to regard bradyi and subglobosa as distinct species, each including variant individuals in which multiple apertures are developed".

Loeblich \& Tappan (1964: C225) followed Höglund (1947) in synonymising Cribrostomoides bradyi Cushman, 1910 with Lituola subglohosum G.O. Sars, 1871 (1872) (sic), citing the latter as the type species of Cribrostomoides Cushman, 1910.

They also synonymised Labrospira (see above) with Cribrostomoitics. In their diagnosis of Cribrostomoides Cushman, 1910, they essentially reverted to the original, stating the chamber arrangement to be "similar to Haplophragmondes" [i.e. planispirall and the aperture to be "areal" (single in "young" and dentate or multiple in "very large" individuals)

Subsequently, Loeblich \& Tappan (1987: 65-66) reinstated Labrospirn and quoted bradyi as the type species of Cribrostomoide's without reference to subglobosus. In their revised diagnosis of the genus, they stated the coiling mode to be "slightly streptospiral" in early stages, later becoming "planispiral and symmetrical". They further stated the aperture to be "cquatorial, just above the base of the final chamber face, ... a simple slit in the early chambers, later ... a linear series of irregular to rounded openings".

\section{OBSERVATIONS ON THE GENUS CRIBROSTOMOIDES CUSHMAN, 1910}

(1) On the type species

The type species (by original designation) of the genus Cribrostomoides Cushman, 1910 is unequivocally
Cribrostomoides bradyi Cushman, 1910. Confusion arises from the arguable synonymy of C. bradyi Cushman, 1910 and $\mathrm{C}$. subglobosus auctt.

The earliest citations of Lituola subglobosa (M. Sars, 1868 (1869); G.O. Sars, 1871 (1872); Brady, 1881a,b) are unaccompanied by figures or descriptions, and are invalid. The next citation (Brady, 1884) synonymised Lituola subglobosa with the fossil species Haplophragmium latidorsatum Bornemann, which is herein regarded as distinct and referable to the genus Haplophragmoides Cushman, 1910. Interestingly, one of the slides in the Brady Collection in the Natural History Museum (BMNH) (which was evidently sent to Brady by Michael Sars) bears the pencilled inscription "Lituola subglobosa" crossed out and replaced by the inked inscription "Haplophragmium latidorsatum" (see our Fig. 2.3). It follows that if Brady had used Sars' designation instead of trying to synonymise it under Bornemann's species, he would have validated subrlobosa in his Challenger Report.

Cushman (1910) was the first to validate the specific name subslobosus, though at the time of writing he was evidently unaware of this. This is noted on an undated addendum slip in the Natural History Museum's edition of the Ellis \& Messina Catalogue of Foraminifera (1940 et seq.) (the full text of which states that "although Cushman credited the specific name [Haplophragmoides (sic) subglobosus] to G.O. Sars it should be credited to Cushman since Sars was responsible for the name alone and not for the description or figures [ICZN, Article 21]".

Both Cribrostomoides bradyi Cushman, 1910 and Hoplophragmoides subglobosus Cushman, 1910 were validated in the same publication (Cushman, 1910), the former species on $p .108$ and the latter on p. 105.

The microfossil collections in the United States National Museum of Natural History, Smithsonian Institution, house about six trays of slides labelled "Cribrostomoides bradyi" and "Haplophragmoides subglobosus" from Albatross and Nero stations studied by Cushman $(1910,1920,1921)$. The bulk of this material is from the North Atlantic (Cushman, 1920), but some is also from the North Pacific (Cushman, 1910) and some from the Philippines (Cushman, 1921). All of the Pacific specimens of both "species" are considered cotypic (syntypic).

Based partly on a study of syntypic suites of both "species", we believe Cribrostomoides bradyi Cushman, 1910 (sce our Fig. 1.4,6; Fig. 2. and Pl. 3) and Haplophragmoides sulghlobosus Cushman, 1910 (see our Fig. 1. 1-3, 5 and Pls. 1,2) to be no more than infra-subspecifically distinct and therefore for practical purposes synonymous (Lukina (1980) reached a similar conclusion). Forma bradyi differs from forma subglobosus essentially only in its size (being larger), and in its wall texture (being finer) and composition (apparently being selective in its use of mafic particles). These differences are interpreted as due to differences in substrate rather than genetic effects (i.e. phenotypic rather than genotypic).

Article 24 of the ICZN (Ride et al., 1985) (the "Principle of the First Reviser") states that "If two ... names are published 

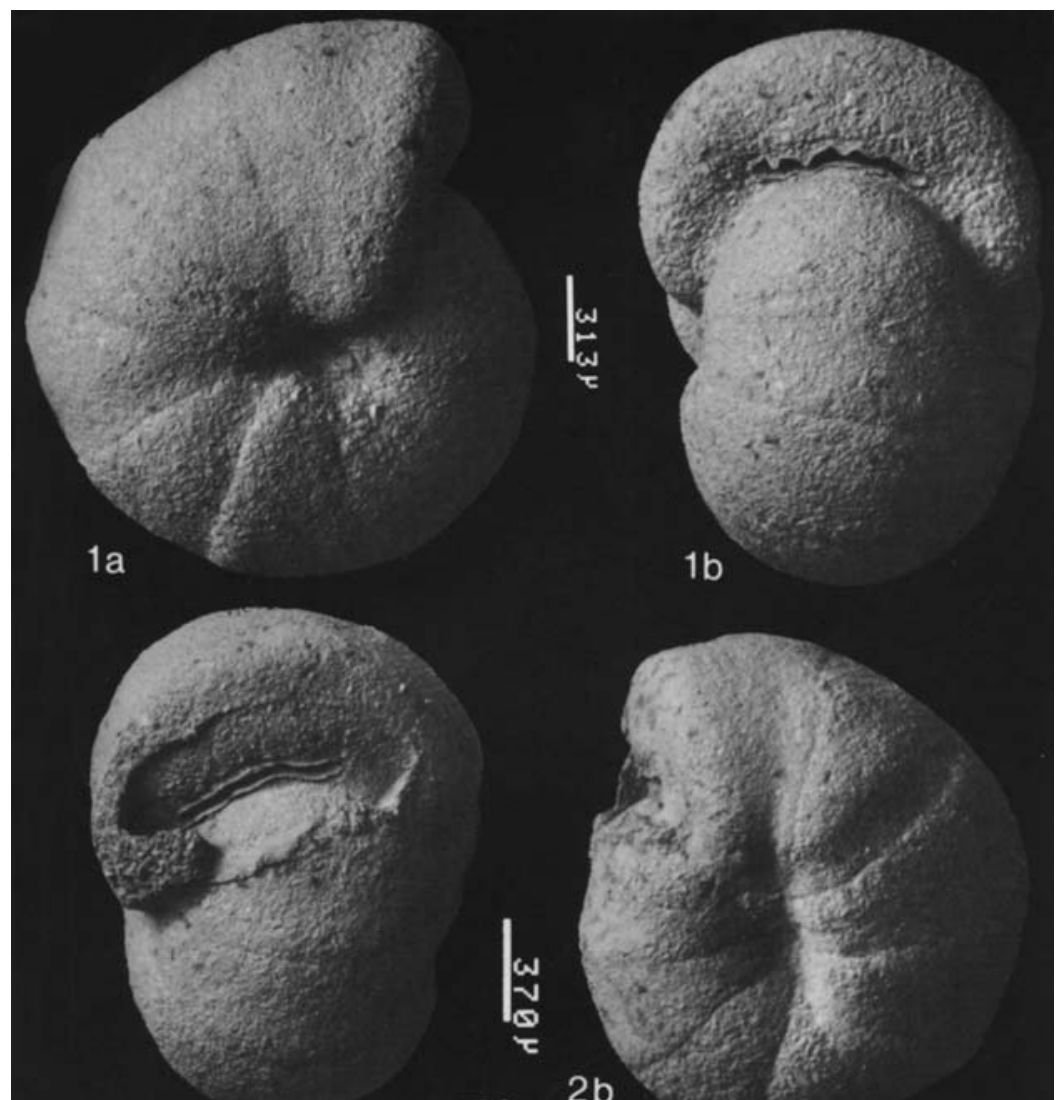

$1 b$

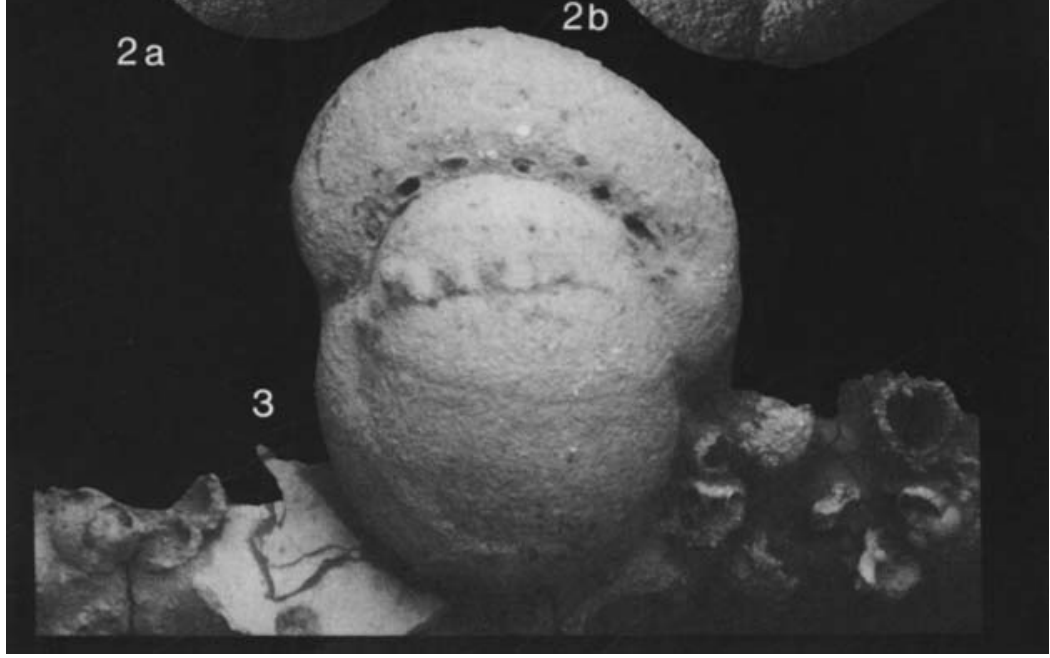

Jones, Bender, Charnock, Kaminski \& Whittaker

Fig. 2. Syntypes of "Cribrostomoides bradyi" from the Cushman Collection. Fig. 2. 1a,b. Cribrostomoides subglobosus forma bradyi (Cushman, 1910). Lectotype (designated herein) of "Cribrostomoides bradyi", North Pacific, Albatross Station D3346, specimen displays crenulated lip, $\times 28$. Fig. 2. 2a,b. Cribrostomoides subglobosus forma bradyi. Paralectotype (designated herein) of "Cribrostomoides bradyi", North Pacific, Albatross Station D3346, specimen without crenulated lip, $\times 28$. Fig. 2.3. Cribrostomoides subglobosus forma bradyi. Brady's specimen of "Haplophragmium latidorsatum", from Challenger Station 246, North Pacific. This specimen was placed by Cushman (1910) in "Cribrostomoides bradyi". BM(NH) ZF1543, x10.

\section{Explanation of Plate 1}

Type specimens of "Cribrostomoides subglobosus". Fig. 1a,b. Cribrostomoides subglobosus forma subglobosus (Cushman, 1910). Lectotype (designated herein) of "Cribrostomoides subglobosus", North Pacific, Albatross Station D3603, 1771 fathoms, USNM 8219b. Specimen illustrated by Cushman (1910) in Textfig. 104. x45. Fig. 2a,b. Cribrostomoides subglobosus forma subglobosus. Paralectotype (designated herein) of "Cribrostomoides subglobosus", North Pacific, NERO Station 160, 1907 fathoms, USNM 8219a, x45. Fig. 3a,b. Cribrostomoides subglobosus forma subglobosus. Lofoten Islands, Norway "very deep water". Specimen was sent to H.B. Brady from the collection of G.O. Sars. Brady Collection, BMNH 1958:11:3:7-12. x63. Fig. 4. Cribrostomoides subglobosus forma subglobosus. Stereo-pair of a specimen sectioned to show involute streptospiral coiling ALBATROSS Station D2572. Slide labelled "Cribrostomoides bradyi" from the Cushman Collection, donated to the British Museum (Natural History). BMNH 1961:1:9:77. Fig. 5. Detail of wall, showing noncanaliculate wall structure, $x 615$. 


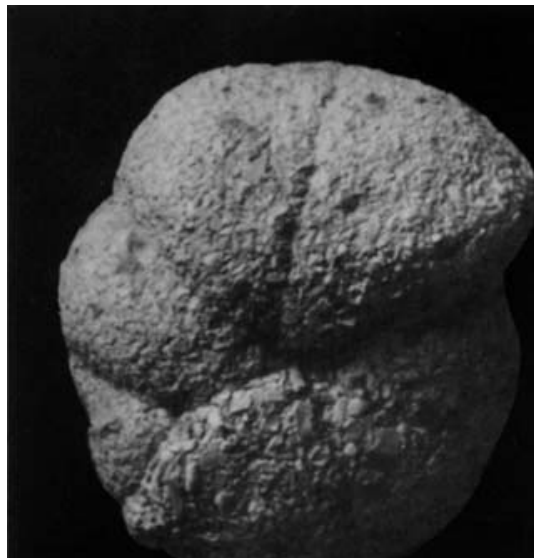

$1 a$

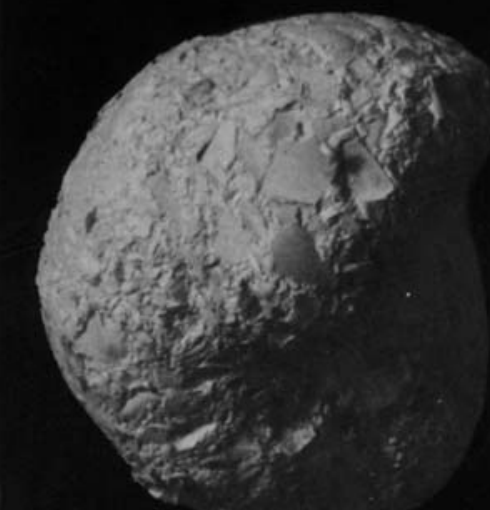

$2 a$

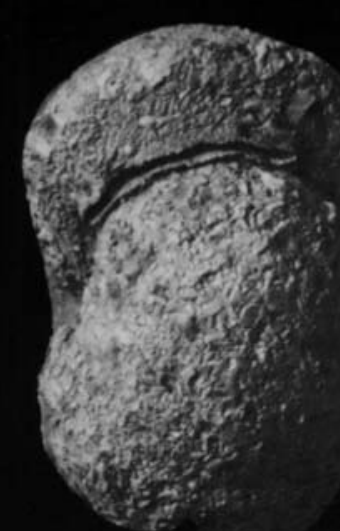

1b
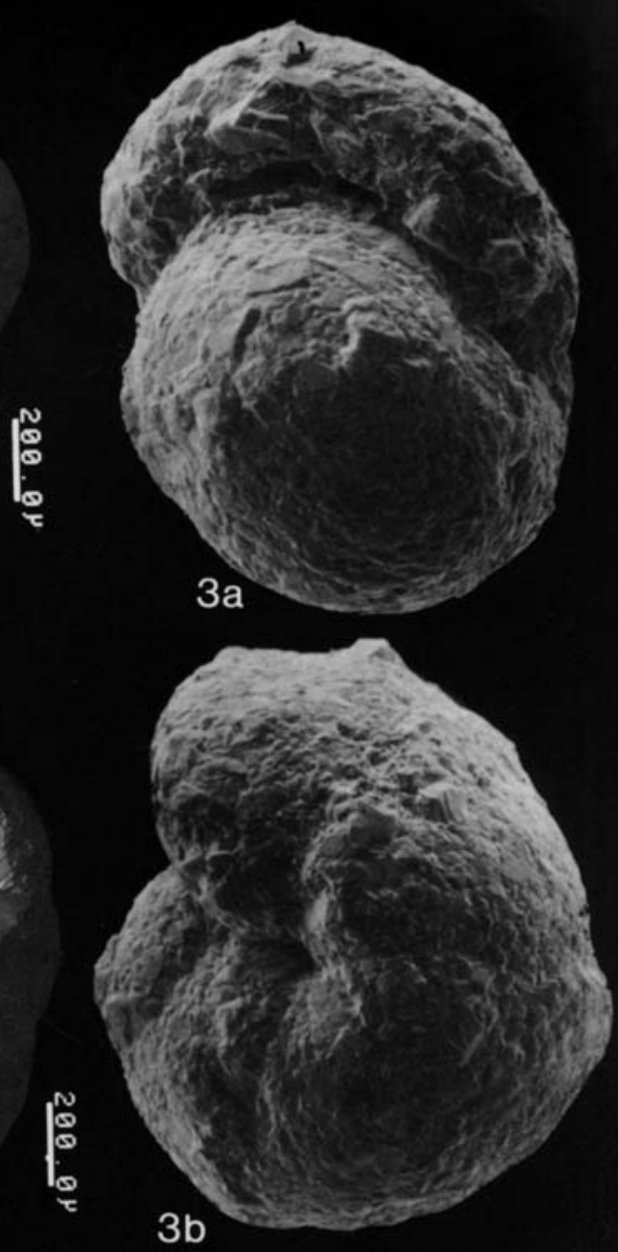

$2 b$
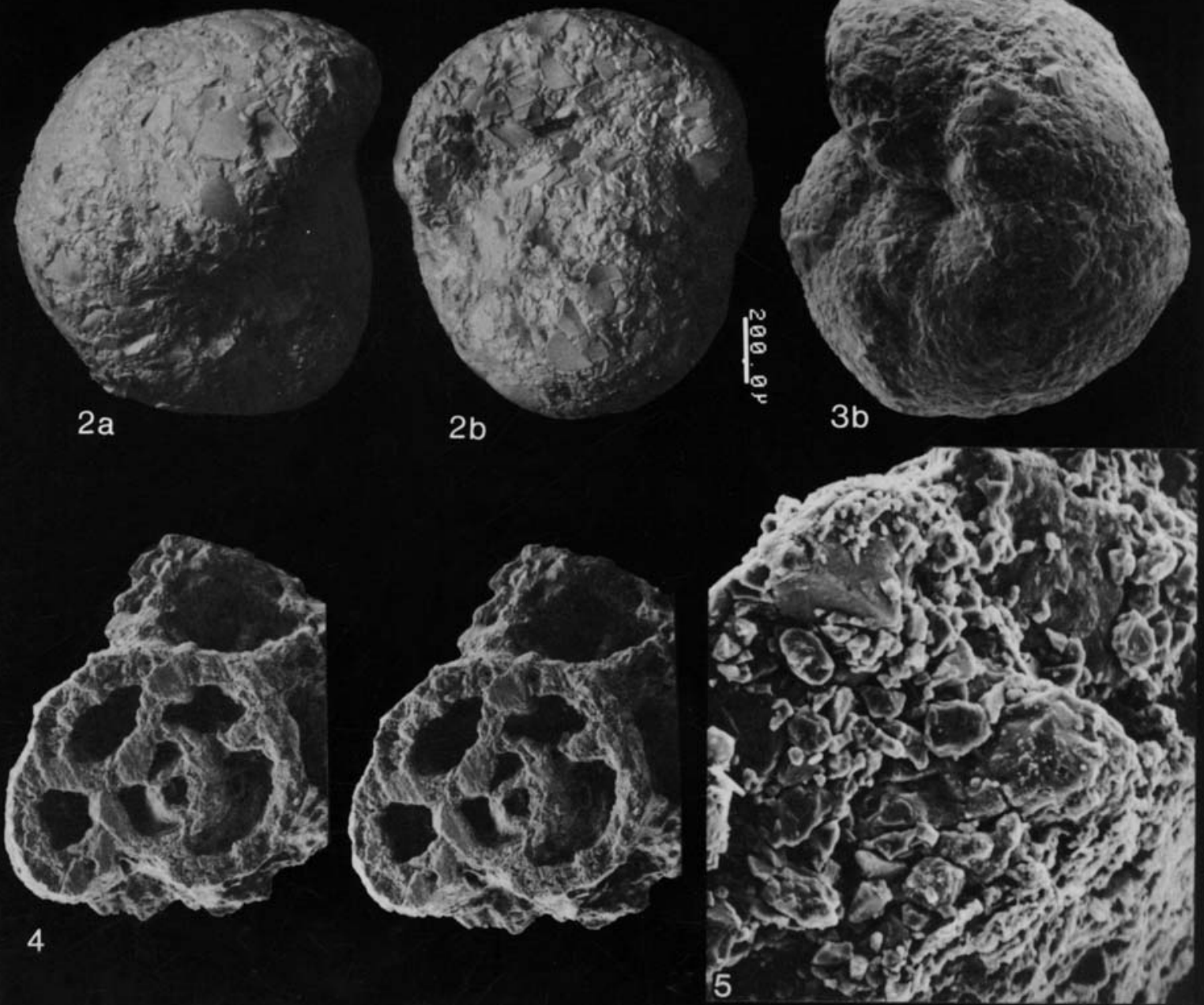

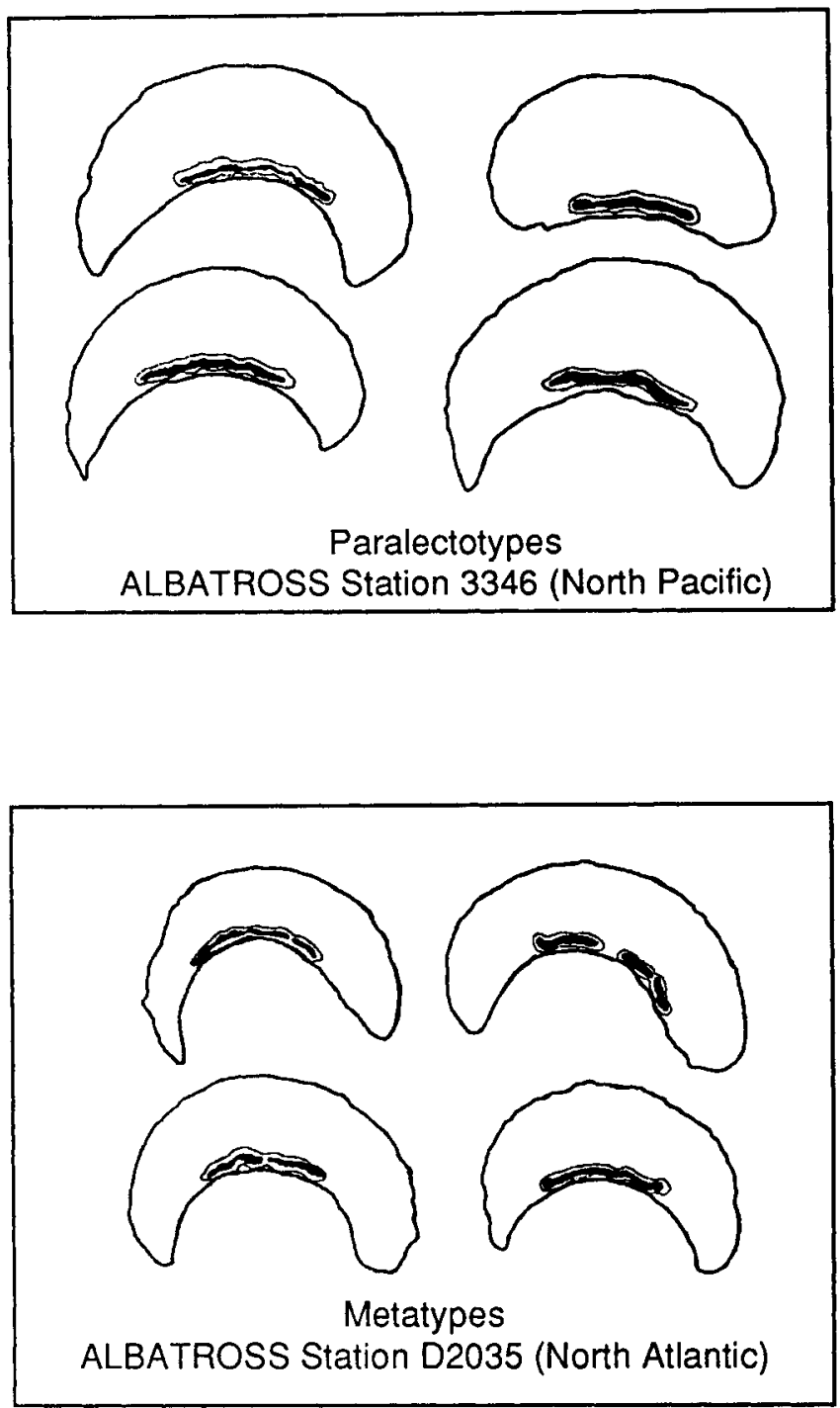

Fig. 3. Apertural characteristics of adult specimens of "Cribrostomoides bradyi". All specimens are from the Cushman Collection (USNM), camera lucida drawings. The paralectotypes have broad apertures with crenulate lips, whereas Atlantic specimens display a greater tendency to possess true multiple apertures. All specimens drawn to the same size.

on the same date, ... in the same or different works, ... by the same or different authors, ... and ... subsequently considered to be synonyms ..., their relative precedence is determined by the first reviser".
We accordingly assign precedence to Haplophragmoides subglobosus Cushman, 1910. This is the more widely used name and the one whose retention would best maintain nomenclatorial stability. It also has "position precedence" (defined as that "given to the the nominal species cited first in the work, page or line"). Recommendation 69B(ll) of the ICZN suggests that this be recognised in the event of "all other things being equal" (Ride et al., 1985).

\section{(2) On the coiling mode}

The widely-held belief (e.g. of Cushman, 1910, Frizzell and Schwartz, 1950, and Loeblich \& Tappan, 1964) that the chamber arrangement in the genus Cribrostomoides is planispiral is in our opinion untenable. This was first called into question by the work of Höglund 1947: 144-145), who noted that Labrospira subglobosa (G.O. Sars) (sic) (which he regarded as a senior synonym of Cribrostomoides bradyi Cushman) "is not formed as a completely flat spiral", that "this is frequently plainly visible in the last volution, which is more or less twisted" and that "the irregularity is particularly noticeable in the initial portion, where the arrangement of the chambers is difficult to determine in a section". Höglund's figured section (Textfigure 126) seems to indicate that later whorls are arranged more or less at right angles to earlier ones. This kind of coiling conforms to that which Banner \& Blow (1967) defined (in the case of the planktonic genus Pulleniatina Cushman) as "streptospiral".

Hofker (1976: 54-55) also observed of Cribrostomoides bradyi Cushman that "especially the early chambers are streptospirally arranged, so that in a section transverse to the last formed coil the whole spiral is seen, whereas in sections in the plane of the last formed coil, several chambers of the first coils are sectioned transversely". He erroneously added that Höglund's subglobosa "does not show" the streptospiral initial part.

In contrast, Loeblich \& Tappan (1964: C225) regarded Cribrostomoides as essentially planispiral. In this work, they defined "streptospiral" genera somewhat imprecisely as "coiled like a ball of twine". Later (1987: 65-66), they came to regard Cribrostomoides as "slightly streptospiral" in early stages, later becoming "planispiral and symmetrical". In this later work they defined streptospiral genera still somewhat imprecisely as "coiled ... in continually changing planes" ( $p$. 741).

Our dissected specimen of Cribrostomoides subglobosus forma subglobosus from the Cushman Collection (Pl. 1, fig. 4) confirms the suspected involute streptospiral coiling mode, characterised by a (repeated) alternation in axis. This is manifest by regular intersections by the plane of section of

\section{Explanation of Plate 2}

Metatypes of "Cribrostomoides bradyi" (specimens identified as such by J.A. Cushman). All specimens are from the Cushman Collection, USNM. Fig. 1a-3b. Cribrostomoides subglobosus forma bradyi. Albatross Station D5613 (42 $\left.{ }^{\circ} 00^{\prime} \mathrm{S}, 121^{\circ} 44^{\prime} \mathrm{W}\right)$, South China Sea, 752 fathoms. USNM 12657. 1a,b- large specimen with crenulated aperture, $x 29 ; 2 a, b-x 42 ; 3 a, b-$ small specimen displaying streptospiral coiling and oval aperture, x57. Fig. 4a-5b. Cribrostomoides subglobosus forma bradyi. Albatross Station D2035 (39 $26^{\prime} \mathrm{N}$, $70^{\circ} 02^{\prime} \mathrm{W}$ ), North Atlantic, 1362 fathoms. USNM 10359, 4a,b- x27; 5a,b- x26. Fig. 6a-8b. Cribrostomoides subglobosus forma subglobosus. Goldseeker Station in the Faeroe-Shetland Channel $\left(61^{\circ} 03^{\prime} \mathrm{N}, 02^{\circ} 20^{\prime} \mathrm{W}\right), 1418 \mathrm{~m}$. Cushman Collection (unregistered slide). 6a,b- large specimen with crenulated apertural lips, $x 46 ; 7 \mathbf{a}-8 \mathbf{b}$ - small specimens displaying streptospiral coiling, $7 \mathbf{a}, \mathbf{b}-\mathrm{x} 43$; $8 \mathbf{8}, \mathbf{b}-\mathbf{x} 54$. 


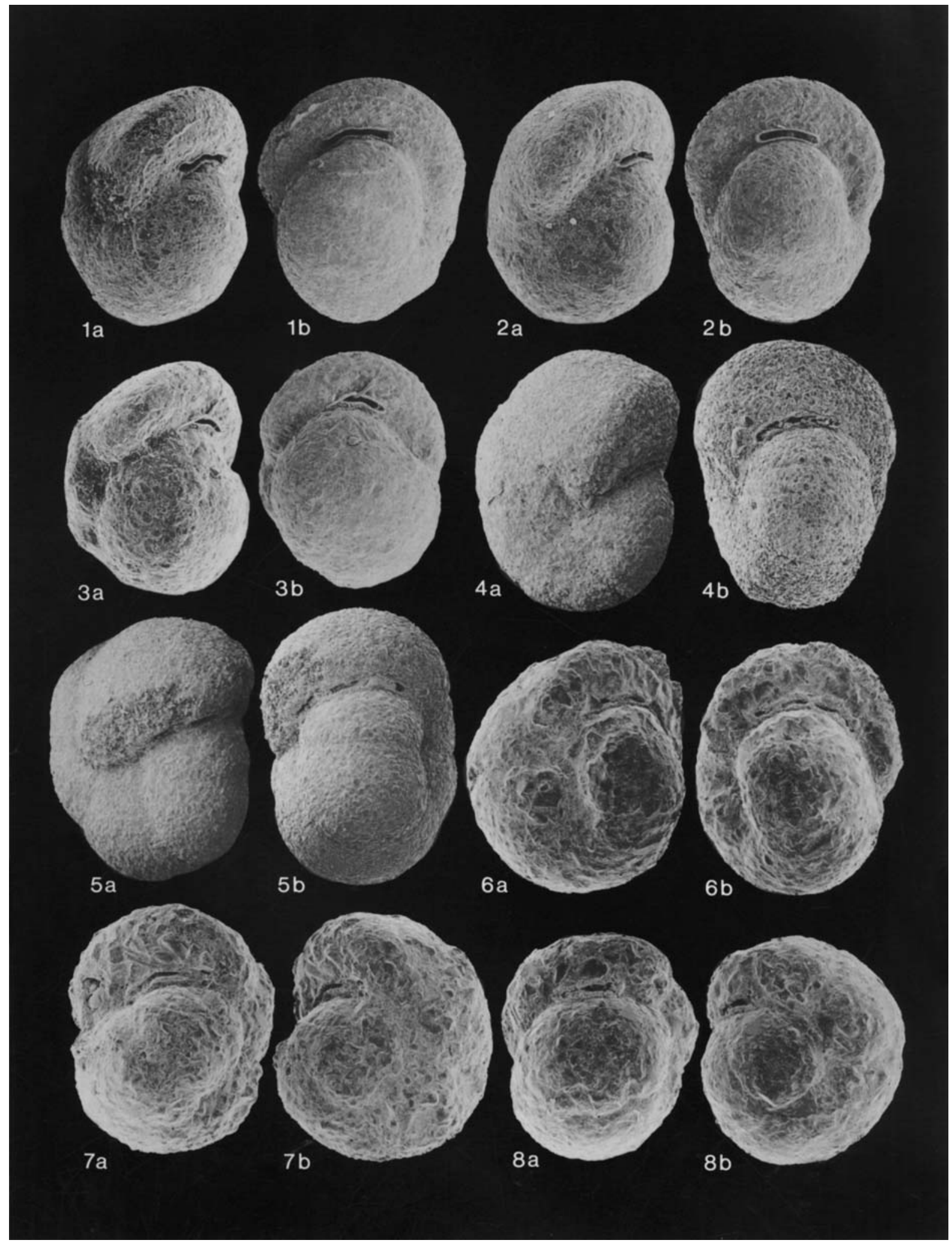


Jones, Bender, Charnock, Kaminski \& Whittaker

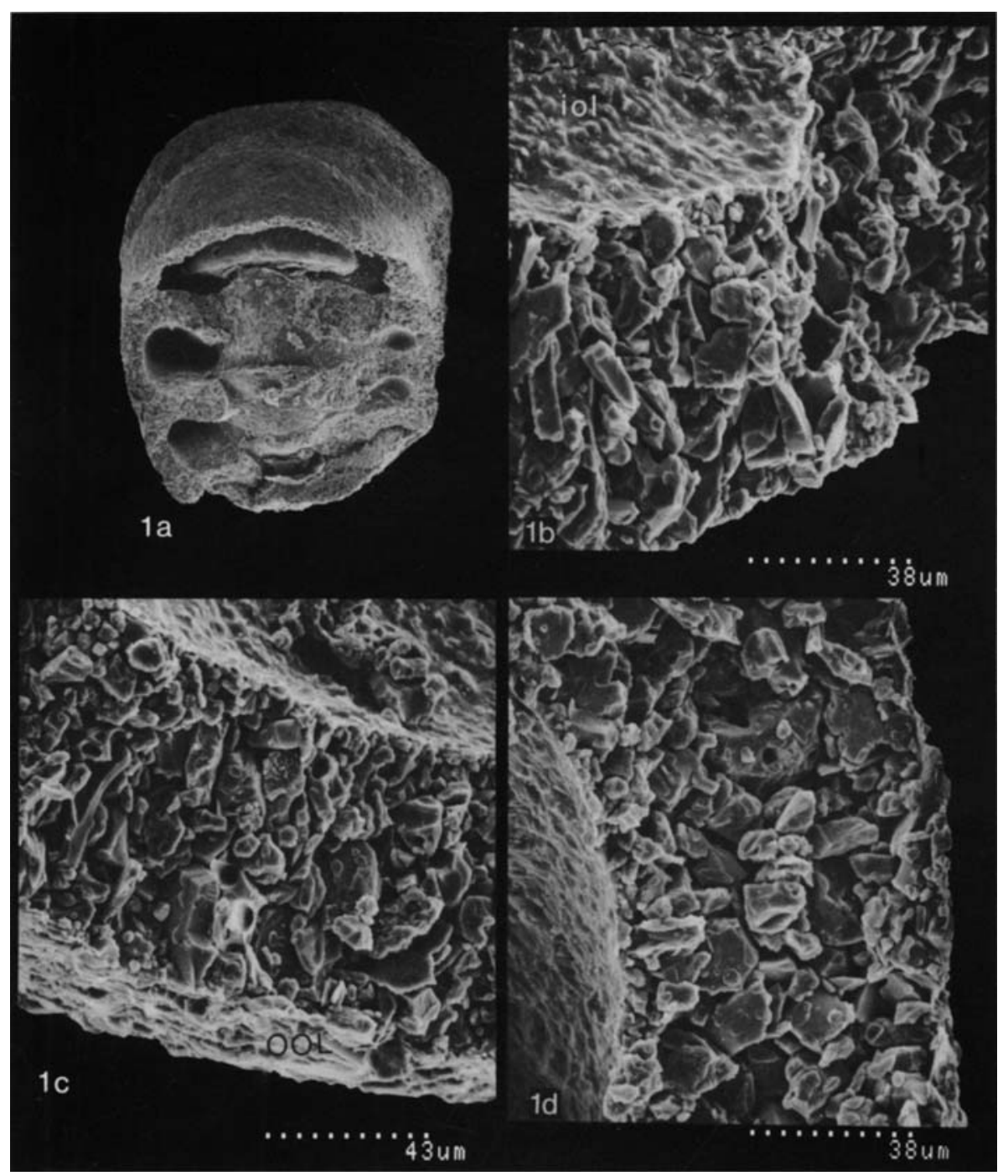

Fig. 4. Wall structure of Cribrostomoides subglobosus forma bradyi. fig. 4.1 Cribrostomoides subglobostus forma bradyi. 1a- Paralectotype sectioned to reveal wall structure $\times 30 ; \mathbf{1 b}$ Detail of wall, showing the inner organic layer (iol), $x 510$; $1 \mathrm{c}-$ wall consists of both biogenic (siliceous) and lithogenic particles with long axes oriented normal to the inner and outer surfaces, (OOL $=$ outer organic layer), $x 510 ; 1$ 1d- Larger particles appear to be concentrated near the centre of the wall, while small particles are placed beneath the IOL and OOL. Undifferentiated organic cement is visible at grain contacts, $x 510$.

the line of communication between successive intercameral foramina and the primary aperture.

(3) On the apertural characteristics

Hofker (1976: 54-55) associated variation in apertural form with alternation of generations in Cribrostomoides bradyi
Cushman (sic). He has demonstrated that morphotypes characterised by single interio-areal apertures represent the megalospheric generation and that those with multiple areal apertures ("with lips which approach each other in several places even to separate the slit into areal openings") are microspheric adults (see also our Fig. 3 ). The former have a proloculus diameter of $33 \mu$ and an overall test diameter of 1.5 - $2 \mathrm{~mm}$ (Al generation) or a proloculus diameter of $46 \mu$ and an overall test diameter of $0.8-1.6 \mathrm{~mm}$ (A2 generation). The latter have a proloculus diameter of $10-18 \mu$ and an overall test diameter of $2-3 \mathrm{~mm}$.

Multiple areal apertures have only been observed in Recent individuals (though this could be a preservational phenomenon or artifact of our sampling). In a few individuals with single elongate apertures the lower lip may be very narrow, giving the impression of an interio-marginal slit. This is also true with the specimen drawn in Brady's (1884) Pl. 34, fig. 7b. A close-up of the aperture reveals the interio-areal position.

\section{(4) On the wall structure}

Both C. subglobosus forma bradyi (Fig. 4) and forma subglobosus (P1. 3) possess a typically tripartate trochamminacean wall structure with a thick agglutinated layer bounded by inner and outer organic layers. The chamber walls of forma bradyi and forma subglobosus are several grains thick with coarse quartz and other mineral particles in a finegrained ground mass. In $C$. subglobosus forma bradyi, both the exterior and interior test surfaces are finely agglutinated and smoothly finished, and coarser particles are concentrated within the chamber wall. In C. subglobosus forma subglobosus, the coarser grains may project outward as well as into the chamber lumen resulting in rough test surfaces. Sectioned, imperforate chamber walls

\section{Explanation of Plate 3}

Wall structure of Cribrostomoides subglobosus forma subglobosus. Fig. 1-3 Norwegian-Greenland Sea, Sample 21697-1 $\left(73^{\circ} 45.1^{\prime} \mathrm{N} / 10^{\circ} 28.5^{\prime} \mathrm{W}\right), 3062 \mathrm{~m}, 1$ - x40; 2- detail of wall showing inner organic layer (iol), x635; 3- detail of wall showing undifferentiated organic cement at particle contacts, $x 3180$. Fig. 4. Ivory Coast, Sample $16802-1\left(4^{\circ} 30.2^{\prime} \mathrm{N} / 6^{\circ} 28.0^{\prime} \mathrm{W}\right), 691 \mathrm{~m} ., x 48$.

Fig. 5-7 Offshore Ghana, Sample 16838-1A, $4^{\circ} 39.0^{\prime} \mathrm{N} / 1^{\circ} 11.0^{\prime} \mathrm{E}, 3736 \mathrm{~m}$. 5- Cross section of wall showing outer organic layer (OOL), $x 1270 ; 6$ - Detail of wall showing inner organic layer and undifferentiated organic cement at particle contacts, x1270; 7-Detail of wall showing inner organic layer with net-like organic cement beneath, $x 6515$. 


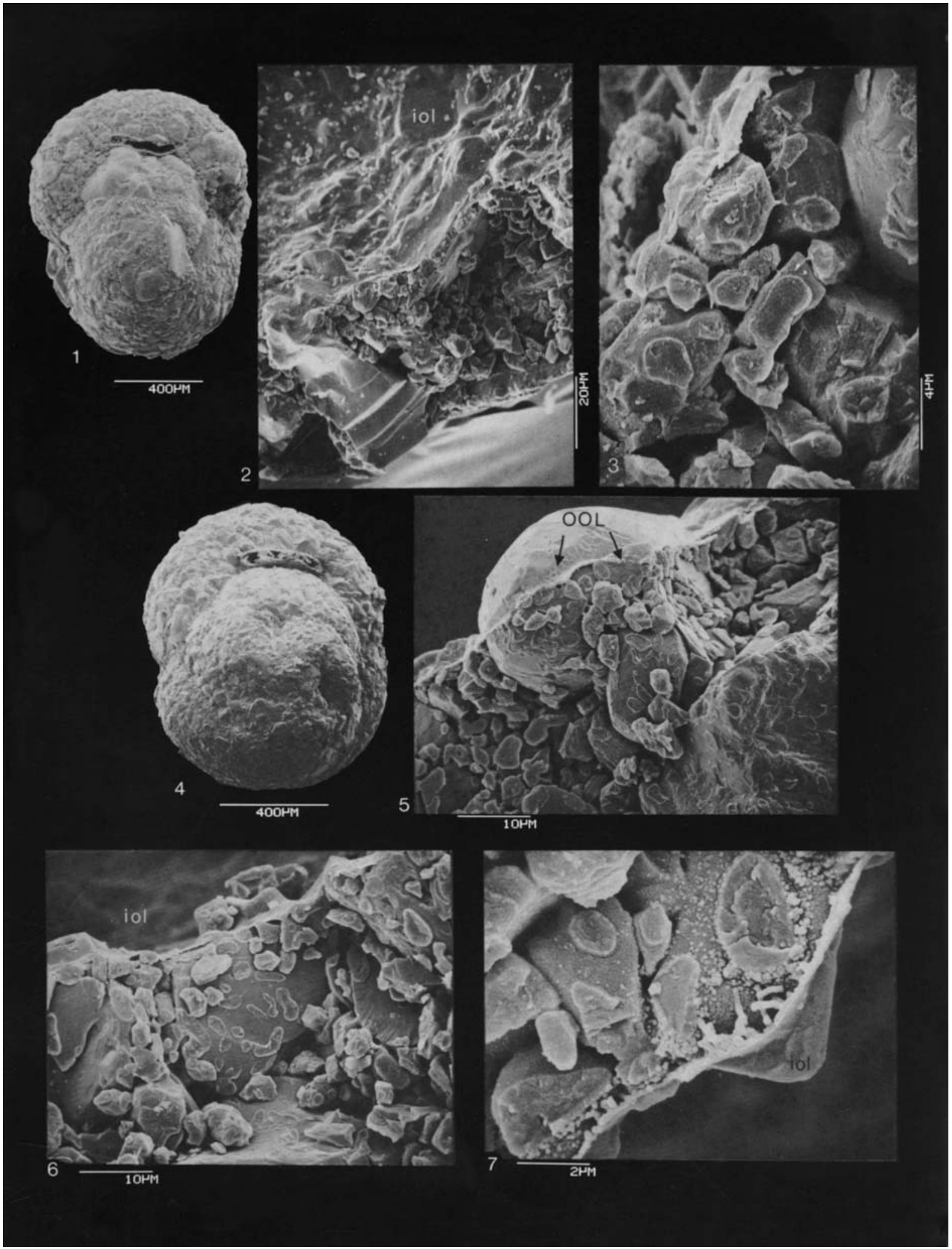




\begin{tabular}{|l|l|l|l|}
\hline \multicolumn{1}{|c|}{ GENUS } & \multicolumn{1}{|c|}{ TYPE SPECIES } & COILING MODE & \multicolumn{1}{|c|}{$\begin{array}{c}\text { APERTURAL } \\
\text { CHARACTERISTICS }\end{array}$} \\
\hline $\begin{array}{l}\text { Cribrostomoides } \\
\text { Cushman, 1910 }\end{array}$ & $\begin{array}{l}\text { C. bradyi Cushman, 1910 } \\
\text { Haplophragmoides subglobosus } \\
\text { Cushman, 1910, O.D. }\end{array}$ & Involute streptospiral & $\begin{array}{l}\text { Interio-areal (megalo.) } \\
\text { areal, multiple (micro.) }\end{array}$ \\
\hline $\begin{array}{l}\text { Cribrostomellus } \\
\text { Saidova, 1970 }\end{array}$ & $\begin{array}{l}\text { C. apertus } \\
\text { Saidova, 1970, O.D. }\end{array}$ & Evolute streptospiral & $\begin{array}{l}\text { Areal, large, multiple, } \\
\text { irregular openings }\end{array}$ \\
\hline $\begin{array}{l}\text { Haplophragmoides } \\
\text { Cushman, 1910 }\end{array}$ & $\begin{array}{l}\text { Nonionina canariensis } \\
\text { d'Orbigny, 1839, O.D. }\end{array}$ & Involute planispiral & Interio-marginal \\
\hline $\begin{array}{l}\text { Recurvoides } \\
\text { Earland, 1934 }\end{array}$ & $\begin{array}{l}\text { Recurvoides contortus } \\
\text { Earland, 1934, O.D. }\end{array}$ & Evolute streptospiral & Interio-areal \\
\hline $\begin{array}{l}\text { Conglophragmium } \\
\text { Bermúdez \& Rivero, 1963 }\end{array}$ & $\begin{array}{l}\text { Trochammina conglobata } \\
\text { Brady, 1884, = T. coronata } \\
\text { Brady, 1879, O.D. }\end{array}$ & $\begin{array}{l}\text { Evolute streptospiral } \\
\text { (irregular, inflated) }\end{array}$ & Interio-marginal \\
\hline $\begin{array}{l}\text { Budashevaella } \\
\text { Loeblich \& Tappan, 1964 }\end{array}$ & $\begin{array}{l}\text { Circus multicameratus } \\
\text { Voloshinova \& Budasheva } \\
\text { 1961, O.D. }\end{array}$ & $\begin{array}{l}\text { Evolute streptospiral } \\
\text { (regular, compact) }\end{array}$ & Interio-marginal \\
\hline $\begin{array}{l}\text { Evolutinella } \\
\text { Myatlyuk, 1971 }\end{array}$ & $\begin{array}{l}\text { E. subevoluta } \\
\text { Nikitina \& Myatlyuk, in } \\
\text { Myatlyuk, 1971, O.D. }\end{array}$ & Evolute planispiral & Interio-marginal \\
\hline $\begin{array}{l}\text { Veleroninoides } \\
\text { Saidova, 1981 }\end{array}$ & $\begin{array}{l}\text { Haplophragmoides veleronis } \\
\text { Cushman \& McCulloch, 1939, } \\
\text { O.D. }\end{array}$ & $\begin{array}{l}\text { Trochammina ringens } \\
\text { Brady, 1879, O.D. }\end{array}$ & Evolute planispiral \\
\hline $\begin{array}{l}\text { Buzasina } \\
\text { Loeblich \& Tappan, 1985 }\end{array}$ & Involute planispiral & Interio-areal \\
\hline
\end{tabular}

Table 1. Criteria for discriminating Cribrostomoides from a number of allied genera. of well-preserved specimens show an inner organic layer as well as a thin outer organic layer (Fig. 4.1b-d; Pl. 3, figs. 2,3, 5-7). In both formae all agglutinated particles are organically enveloped and firmly glued together with organic cement. In the distal parts of the chamber wall the cement is developed as morphologically undifferentiated substance which joins particles at their points of contact Fig. 4.1d, Pl. 3, figs. 3,5,6), while in proximal parts of the wall it may have a net-like appearance (Pl. 3, fig. 7). The organic nets are expecially found in contact with the inner organic layer, although they may be incomplete in some chamber wall areas.

\section{DESIGNATION OF LECTOTYPE FOR HAPLOPHRAG- MOIDES SUBGLOBOSUS CUSHMAN, 1910}

The specimen designated as lectotype of Haplophragmoides subglobosus Cushman, 1910 (United States National Museum of Natural History [USNM] Registered Number USNM8219b) has been chosen from the original syntypic suite of that species. The specimen (Pl. 1, fig. 1a,b) is from Albatross Station D3603 in the North Pacific $(1771 \mathrm{fm}$ or $3241 \mathrm{~m}$ ), material from which was certainly available to Cushman at the time he was working on his "Monograph of the Foraminifera of the North Pacific Ocean" (1910). The lectotypification is therefore in accordance with Article 74(a) of the ICZN (Ride et al., 1985), which states that "If a type series contains more than one specimen and a holotype has not been designated, any author may designate one of the syntypes as a lectotype...".

The lectotype is housed in a slide bearing annotations to the effect that it is a "plesiotype" probably representing the specimen figured as Textfig. 164 on p. 106 of the "North Pacific Monograph" (Cushman, 1910) (a plesiotype is a figured specimen used subsequently to the original description). The lectotypification is therefore also in accordance with Recommendation $74 \mathrm{~B}$ of the ICZN, which states that "other things being equal, an author who designates a lectotype should give preference to a syntype of which an illustration has been published".

The remaining former syntypes of $H$. subglobosus Cushman, 1910 become paralectotypes in accordance with Article $74 \mathrm{a}$ (iv) of the ICZN, which states that "The valid designation of a lectotype permanently deprives all specimens that were formerly syntypes ... of the status of syntype [Art. $73 b$ (ii)]; those species become paralectotypes [Rec. 74F]".

\section{DESIGNATION OF LECTOTYPE FOR CRIBROSTOMOIDES BRADYI CUSHMAN, 1910}

The specimen designated as lectotype of Cribrostomoides bradyi Cushman, 1910 (hitherto unregistered by the USNM) has also been chosen from the original syntypic suite of that species. The specimen (Fig. 2. 1a,b) is from Albatross Station D3346 in the North Pacific, material from which was certainly available to Cushman at the time he was working on his "North Pacific Monograph" (Cushman, 1910). The lectotypification is therefore in accordance with Article 74(a) of the ICZN (Ride et al., 1985; see also above). The remaining former syntypes of $C$. bradyi Cushman, 1910 become paralectotypes in accordance with Article 74a(iv) of the ICZN.

EMENDED DIAGNOSIS OF THE GENUS CRIBROSTOMOIDES 
Cribostomoides Cushman, 1910, pps. 108109 [C. bradyi Cushman, 1910, pps. 108-109= Haplophragmoides subglobosus Cushman, 1910: 105-106 (herein lectotypified); O.D.] [= Lituola auctt., non Lamarck, 1804; Haplophragmium auctt., non Reuss, 1860; Haplophragmoides Cushman, 1910: 99 (pars); Cribrostomoides Cushman, 1910: 108-109; Labrospira Höglund, 1947].Test free, coiled in an involute streptospire, characterised by a (repeated) alternation in axis (usually of ninety degrees); wall agglutinated, solid, imperforate, consisting of a multiple layer of mineral particles covered by an inner and outer organic lining, cement organic, aperture equatorial or slightly asymmetrically placed, interio-areal and single to areal and multiple, surrounded by lips.

\section{Geographical Distribution}

The geographical distribution of Cribrostomoides appears to be worldwide based on the following records: Arctic, Brady (1881a,b), Vilks (1969), Jones (1984, MS); Atlantic (including Caribbean and Gulf of Mexico) and borderlands, Brady (1884), Flint (1899), Cushman (1910, 1920), Höglund (1947), Galhano (1963), Leroy \& Hodgkinson (1975), Hofker (1976), Pflum \& Frerichs (1976), Pearce (1980, MS), Lutze (1980), Cole (1981), Culver \& Buzas (1982), Schafer \& Cole (1982), Schafer et al. (1983), Jones (1984, MS), Murray \& Taplin (1984) (after Carpenter (1868)), Mackensen et al. (1985); Pacific and borderlands, Brady (1884), Cushman (1910), Theyer (1971), Smith (1973), Saidova (1975), Zheng (1988), Zheng and Fu (1988), Mackensen \& Douglas (1989); Southern Occan and Antarctic, Brady (1884), Herb (1971), Anderson (1975), Lindenberg \& Auras (1984), Mackensen \& Douglas (1989), Mackensen et al. (1990).

The majority of occurrences are cither in comparatively shallow (shelf to upper bathyal) depths in high latitudes or comparatively deep (middle bathyal to abyssal) depths in low to moderate latitudes. The inference is that it is a stenothermal, cryophilic genus. Recent evidence suggests that it might be infaunal in habit (Mackensen \& Douglas, 1989).

\section{Stratigraphic Range}

The stratigraphic range of Cribrostomoides appears to extend from the Late Cretaceous to the Recent based on the following records: Late Cretaceous - Early Tertiary, Labrador Sea, Miller et a1. (1982); Maastrichtian Palaeogene, Labrador and North Seas, Gradstein \& Berggren (1981); Santonian - Palaeocene, Central North Sea, Charnock \& Jones (1990); Late Pleistocene, Denmark Strait, Norwegian-Greenland Sea and Iberian Abyssal Plain, Jones (1984, MS); late Quaternary, Norwegian Sea, Sen Gupta (1984).

\section{TAXONOMIC IMPLICATIONS}

Our emendation of Cribrostomoides Cushman, 1910 affects the interpretation of its relationship to a number of allied genera. Cribrostomoides Cushman, 1910, as emended herein, is distinguished from Haplophragmoides Cushman, 1910, emend. Höglund, 1947 and Evolutinella Myatlyuk, 1971 on. the basis of its streptospiral rather than planispiral coiling and interio-areal rather than interio-marginal aperture, respectively; from Recurvoides Earland, 1934, emend. Uchio, 1960 on the basis of its involute rather than evolute streptospiral coiling and inflated rather than compressed test; from Conglophragmium Bermúdez \& Rivero, 1963 in its well-formed chambers; from Martyschiella Myatliuk, 1966 and Thalmmanorecurooides Sandulescu, 1971 on the basis of its involute rather than evolute streptospiral coiling and interio-areal rather than interio-marginal aperture, respectively; from Budashevaella Loeblich \& Tappan, 1964 on the basis of its involute rather than evolute streptospiral coiling, interio-areal rather than interio-marginal aperture and inflated rather than compressed test; from Veleroninoides Saidova, 1981 on the basis of its involute streptospiral rather than evolute planispiral coiling; from Cribrostomellus Saidova, 1970 on the basis of its organic rather than calcareous cement, and from Buzasina Loeblich \& Tappan, 1985 (and its synonym Cystamminella Lukina, 1980, non Myatlyuk, 1966) on the basis of its streptospiral rather than planispiral coiling. Criteria for the discrimination of the aforementioned genera are summarised on Table 1.

Labrospira Höglund, 1947 is automatically a synonym of Cribrostomoides Cushman, 1910 because Höglund included the type species of the latter genus in his description of the former. In our opinion, evolute planispiral species with interio-areal apertures previously erroneously included in Labrospira Höglund, 1947 should now be transferred to Veleroninoides Saidova, 1981. We are currently reviewing the genus Recurvoidella Uchio, 1960 partly in order to elucidate the nature of its relationship with Cribrostomoides Cushman, 1910 .

\section{ACKNOWLEDGEMENTS}

We gratefully acknowledge Richard Hodgkinson of the Natural History Museum, London and Toby Stiles (UCL) for technical assistance. Brian Huber of the Smithsonian Institution, Washington DC loaned specimens and kindly allowed us to photograph them in the BMNH's "Environmental Chamber". Thanks are due to G.F. Lutze (CAU-Kiel) who provided specimens from the Meteor Collection. British Petroleum and Simon Petroleum Technology are thanked for permitting RWJ and MAC respectively to publish this paper. This is Contribution no. 36 of the Deep-Water Agglutinated Foram Project.

\section{Manuscript received December 1992 Manuscript accepted July 1993}

\section{REFERENCES}

Anderson, J.B., 1975. Ecology and Distribution of Foraminifera in the Weddell Sea of Antarctica. Micropaleontology, 21, 69-96.

Banner, F.T. \& Blow, W.H., 1967. The Origin, Evolution and Taxonomy of the Foraminiferal Genus Pulleniatina Cushman, 1927. Micropaleontology, 13, 133-162.

Bermúdez, P.J. \& Rivero, F.C., 1963. Estudio Sistematico de los Foraminiferos Quitinosos, Microgranulares y Arenaceos. 
Caracas; Universidad Central Venezuela

Bornemann, J.G., 1855. Die Mikroskopische Fauna des Septarienthones von Hermsdof bei Berlin. Zeitschrift der Deutschen Geologischen Gesellschaft, 7, 307-371.

Brady, H.B., 1879. Notes on some Reticularian Rhizopoda of the "Challenger" Expedition. Part 1. On New or Little Known Arenaceous Types. Quarterly Journal of Microscopical Science, new ser., 19, 20-63.

Brady, H.B., 1881a. On some Arctic Foraminifera from Soundings Obtained on the Austro-Hungarian North-Polar Expedition of 1872-1874. Annals and Magazine of Natural History, ser. 5, 8, 393-418.

Brady, H.B., 1881b. Uber Einige Arktische TiefseeForaminiferen, Gesammelt Wahrend der OsterreichischUngarischen Nordpol-Expedition 1872-1874. Denkschriften der Kaiserlichen Akademie der Wissenschaften, Wien, MathematischNaturwissenschaftliche Klasse, 43, 91-110.

Brady, H.B., 1884. Report on the Foraminifera Dredged by HMS Challenger During the Years 1873-1876. Report on the Scientific Results of the Voyage of the H.M.S. Challenger during the years 1873-1876, Zoology, 9, 1-814.

Carpenter, W.B., 1868. Preliminary Report of Dredging Operations in the Seas to the North of the British Islands, carried out in Her Majesty's Steam-Vessel "Lightning" by Dr. Carpenter and Dr. Wyville Thomson, Professor of Natural History in Queen's College, Belfast. Proceedings of the Royal Society, 17, 168-200.

Charnock, M.A. \& Jones, R.W., 1990. Agglutinated Foraminifera from the Palaeogene of the North Sea. In Hemleben, C., Kaminski, M.A., Kuhnt, W. \& Scott, D.B. (Eds.): Paleoecology, Biostratigraphy, Paleoceanography and Taxonomy of Agglutinated Foraminifera (Proceedings of the Third International Workshop on Agglutinated Foraminifera, Tübingen, 1989), 139-244. Dordrecht, Boston, London; Kluwer Academic Publishers

Cole, F.E., 1981. Taxonomic Notes on the Bathyal Zone Benthonic Foraminiferal Species off Northeast Newfoundland. Bedford Institute of Oceanography, Dartmouth, Nova Scotia, Canada, Report Series, BI-R-81-7.

Culver, S.J. \& Buzas, M.A., 1982. Foraminiferal Provinces between Newfoundland and Yucatan. In Sen Gupta, B.K. \& Buzas, M.A.: Quaternary Benthic Foraminifera of North American Continental Margins. Bulletin of the Geological Society of America, 93, 269-277.

Cushman, J.A., 1910. A Monograph of the Foraminifera of the North Pacific Ocean. Pt. 1. Astrorhizidae and Lituolidae. Bulletin of the United States National Museum, 71, 1-134.

Cushman, J.A., 1920. The Foraminifera of the Atlantic Ocean. Pt. 2. Lituolidae. Bulletin of the United States National Museum, 104, 1-111.

Cushman, J.A., 1921. Foraminifera of the Philippines and Adjacent Seas. United States National Museum Bulletin, 100(4), $1-608$.

Cushman, J.A. \& Jarvis, P.W., 1928. Cretaceous Foraminifera from Trinidad. Contributions from the Cushman Laboratory for Foraminiferal Research, 4, 85-103.

Cushman, J.A. \& Jarvis, P.W., 1932. Upper Cretaceous Foraminifera from Trinidad. Proceedings of the United States National Museum, 80(14), 1-60.

Cushman, J.A. \& McCulloch, I., 1939. A Report on Some Arenaceous Foraminifera. Allan Hancock Pacific Expeditions, 6(1), 1-113.
Earland, A., 1934. Foraminifera, Part III. The Falklands Sector of the Antarctic (excluding South Georgia). Discovery Reports, 10, 1-208.

Ellis, B.F. \& Messina, A.R., 1940 et seq. Catalogue of Foraminifera. American Museum of Natural History.

Flint, J.M., 1899. Recent Foraminifera, a Descriptive Catalogue of Specimens Dredged by the US Fish Steamer Albatross. Report of the United States National Museum, 1897, 249-349.

Frizzell, D.L. \& Schwartz, E., 1950. A New Lituolid Foraminiferal Genus from the Cretaceous, with an Emendation of Cribrostomoides Cushman. University of Missouri, Technical Series, Bulletin, 76, 1-12.

Galhano, M.A., 1963. Foraminiferos de Costa de Portugal (Algarve). Publicaciones del Instituto Geologico, 89, 1-110.

Geroch, S., 1962. Thalmannammina and Plectorecurvoides (Foraminifera) in the Lower Cretaceous of the Flysch Carpathians. Rocznik Polskiego Towarzystwa Geologicznego, 32(2), 281-300.

Gradstein, F.M. \& Berggren, W.A., 1981. Flysch-Type Agglutinated Foraminifera and the Maestrichtian to Paleogene History of the Labrador and North Seas. Marine Micropaleontology, 6, 211-268.

Herb, R., 1971. Distribution of Recent Benthonic Foraminifera in the Drake Passage. Antarctic Research Series, 17, 251-300.

Hofker, J., 1976. Further Studies on Caribbean Foraminifera. Studies on the Fauna of Curaçao and other Caribbean Islands, 49(162), 1-256.

Höglund, H., 1947. Foraminifera in the Gullmar Fjord and Skagerak. Zoologiska Bidrag Fran Uppsala, 26, 1328.

Jones, R.W., 1984, MS. Late Quaternary Benthonic Foraminifera from Deep-Water Sites in the North-East Atlantic and Arctic. Unpublished doctoral dissertation, University College of Wales, Aberystwyth, 3 vols.

Lamarck, J.B., 1804. Suite des Memoires sur les Fossiles des Environs de Paris. Annales du Museum National d'Histoire Naturelle, 5, 237-245.

Leroy, D.O. \& Hodgkinson, K.A., 1975. Benthonic Foraminifera and some Pteropoda from a Deep-Water Dredge Sample, Northern Gulf of Mexico. Micropaleontology, 21, 420-447.

Lindenberg, H.G. \& Auras, A., 1984. Distribution of Arenaceous Foraminifera in Depth Profiles of the Southern Ocean (Kerguelen Plateau Area). Palaeogeography, Palaeoclimatology \& Palaeoecology, 48, 61-106.

Loeblich, A.R., Jr. \& Tappan, H., 1964. Protista 2, Sarcodina chiefly "Thecamoebians" and Foraminiferida. In Moore, R.C. (Ed.): Treatise on Invertebrate Paleontology, Part C Geological Society of America and University of Kansas Press, 2 vols.

Loeblich, A.R., Jr. \& Tappan, H., 1985. Some New and Redefined Genera and Families of Agglutinated Foraminifera. I. Joumal of Foraminiferal Research, 15, 91-104.

Loeblich, A.R., Jr. \& Tappan, H., 1987. Foraminiferal Genera and their Classification. New York; Van Nostrand Reinhold: 2 vols.

Lukina, T.G., 1980. Deep Sea Foraminifera of the Central Part of the Pacific Ocean. Zoologicheskikh Institut, Akademiya Nauk SSSR, Issledovaniya Fauny Morey, 24(32), 1-203 (in Russian).

Lutze, G.F., 1980. Depth distribution of benthic foraminifera on the continental margin off NW Africa. "Meteor" ForschungsErgebnisse, Reihe C, 32, 31-80.

Mackensen, A. \& Douglas, R.G., 1989. Down-Core Distribution 
of Live and Dead Deep-Water Benthic Foraminifera in BoxCores from the Weddell Sea and the California Continental Borderland. Deep-Sea Research, 36, 879-900.

Mackensen, A., Grobe, H., Kuhn, G. \& Futterer, D.K., 1990. Benthic Foraminiferal Assemblages from the Eastern Weddell Sea between 68 and $73 \mathrm{deg}$. S: Distribution, Ecology and Fossilization Potential. Marine Micropaleontology, 16, 241283.

Mackensen, A., Sejrup, H.P. \& Jansen, E., 1985. The Distribution of Living Benthic Foraminifera on the Continental Slope and Rise off Southwest Norway. Marine Micropaleontology, 9, 275306.

Miller, K.G., Gradstein, F.M. \& Berggren, W.A., 1982. Late Cretaceous to Early Tertiary Agglutinated Benthic Foraminifera in the Labrador Sea. Micropaleontology, 28, 1-30.

Murray, J.W. \& Taplin, C.M., 1984. Larger Agglutinated Foraminifera from the Faeroe Channel and Rockall Trough collected by W.B. Carpenter. Journal of Micropalaeontology, 3, 59-62.

Myatlyuk, E.V., 1971. On the Systematics of Planispiral Representatives of the Haplophragmoididae (Foraminifera). Trudy Vsesyuznogo Nauchno-issledvatel'skogo Geologorazvedochnogo Instituta (VNIGRI), 291, 18-25 (in Russian).

Norman, A.M., 1892. Museum Normanianum, Pt. 7-8. Durham; The Author: pps. 14-21.

d'Orbigny, A.D., 1839. Foraminiferes. In Barker-Webb, P. \& Berthelot, S.: Histoire Naturelle des Iles Canaries, Vol. 2, Pt. 2, Zoologie, 119-146. Paris; Bethune.

Pearce, G.J., 1980, MS. Benthonic Foraminifera from the Continental Slope and their Fossil Counterparts. Unpublished doctoral dissertation, University College of Wales, Aberystwyth, 2 vols.

Pflum, C. \& Frerichs, W., 1976. Gulf of Mexico Deep-Water Foraminifers. Cushman Foundation for Foraminiferal Research Special Publication, 14, 1-125.

Pokorny, V., 1951. Thalmannammina n. g. (Foraminifera) z Karpatskeho Flyse. Sbornik Ustredniho Ustavu Geologickeho, 18, 469-479.

Reuss, A.E., 1860. Die Foraminiferen der Westphalischen Kreideformation. Sitzungsberichte der Kaiserlichen Akademie der Wissenschaften, Wien, Mathematisch-Naturwissenschaftliche Klasse, 40, 147-238.

Ride, W.D.L., Sabrosky, C.W., Bernardi, G. \& Melville, R.V. (Eds., 1985. International Code of Zoological Nomenclature. Third Edition. Adopted by the XX General Assembly of the International Union of Biological Sciences. Berkeley and Los Angeles; University of California Press.

Saidova, Kh. M., 1970. Benthic Foraminifera from the Region of the Kurile-Kamchatka Trench (Based on Data from the 39th Cruise of the R/V Vityaz). Trudy Instituta Okeanologii, 86 (in Russian).
Saidova, Kh. M., 1975. Benthonic Foraminifera of the Pacific Ocean. Moscow; Institut Okeanologii P.P. Shirshova, Akademiya Nauk SSSR (in Russian).

Saidova, Kh. M., 1981. On an Up-to-Date System of Supraspecific Taxonomy of Cenozoic Benthonic Foraminifera. Moscow; Institut Okeanologii P.P. Shirshova, Akademiya Nauk SSSR (in Russian).

Sars, G.O., 1872. Undersogelser over Hardangerfjordens Fauna. Forhandlinger $i$ Videnskasselskabet $i$ Kristiania, 1871, 246-255.

Sars, M., 1869. Fortsatte Bemaerkinger over det Dyriske Livs Udbredning i Havets Dybder. Forhandlinger $i$ Videnskasselskabet $i$ Kristiania, 1868, 246-275.

Schafer, C.T. \& Cole, F.T., 1982. Living Benthic Foraminiferal Distributions on the Continental Slope and Rise East of Newfoundland. In Sen Gupta, B.K. \& Buzas, M.A.: Quaternary Benthic foraminifera of North American Continental Margins. Bulletin of the Geological Society of America, 93, 207-217.

Schafer, C.T., Cole, F.T. \& Carter, L., 1983. Paraecology of Bathyal zone Arenaceous Foraminifera: Genera and Species Associations off Northeast Newfoundland. In Verdenius, J.G., van Hinte, J.E. \& Fortuin, A.R. (Eds.): Proceedings of the First Workshop on Arenaceous Foraminifera, 7-9 September 1981, 133-145. Trondheim; Institut for Kontinentalsokkelundfersokelser.

Sen Gupta, B.K., 1984. Late Quaternary Benthic Foraminifera of the Southern Norwegian Sea. In Oertli, H. (Ed.): Benthos '83 (Proceedings of the Second International Symposium on Benthic Foraminifera, Pau, April 1983), 551-555. Pau et Bordeaux; Elf-Aquitaine.

Smith, P.B., 1973. Foraminifera of the North Pacific Ocean. U.S. Geological Survey Professional Paper, 766, 1-27.

Theyer, F., 1971. Benthic Foraminiferal Trends, PacificAntarctic Basin. Deep-Sea Research, 18(7), 723-738.

Uchio, T., 1960. Ecology of Living Benthonic Foraminifera from the San Diego, California, Area. Cushman Foundation for Foraminiferal Research Special Publication, 5, 1-72.

Vilks, G., 1969. Recent foraminifera in the Canadian Arctic. Micropaleontology, 15, 35-60.

Voloshinova, N.A. \& Budasheva, A.I., 1961. Lituolidae and Trochamminidae from Tertiary Strata of Sakhalin Island and Kamchatka Peninsula. Trudy Vsesyuzıogo Naudmo-issledvatel'skogo Geologorazvedochnogo Instituta (VNIGRI), 170, 169-233.

Zheng, S., 1988. The Agglutinated and Porcelaneous Foraminifera of the East China Sea. Beijing, $337 \mathrm{pp}$.

Zheng, S. \& Fu, Z., 1988. The Distribution of Agglutinated Foraminifera in the East China Sea. In Benthos ' 86 (Proceedings of the Third International Symposium on Benthonic Foraminifera, Geneva, 1986), 929-949. Geneva. 